\title{
Cowboy Cops and Black Lives Matter: Three Billboards Outside Ebbing, Missouri and the Great White West[ern]
}

\section{ABSTRACT}

The racial framework of Martin McDonagh's 2017 film Three Billboards Outside Ebbing, Missouri rests at the intersection of three persistent cultural myths - the Frontier Myth, the hero cowboy myth and the myth of white supremacy. There has been much criticism of the portrayal of black characters in the film, and particularly the lack of significant black characters in a film that sports a solid undercurrent of racial politics. While the black characters in the film occupy a small amount of screen time, this paper argues that the film's treatment of black characters, including their absence, puts on display the cultural dysfunction of racial politics in the US, especially in rural America, and particularly in Missouri. The film's subversion of the cowboy hero instead reveals the disturbing reality of the Frontier Myth and its dependence on racism and white supremacy for validation. In its unmasking of myth, Three Billboards challenges the illusion of a glorious Western past that never existed and at the same time supports racial justice and the Black Lives Matter movement.

Keywords: race, Black Lives Matter, the Western, Missouri, the Frontier Myth. 


\section{INTRODUCTION}

In West of Everything, Jane Tompkins describes the Western narrative as presenting "strength as the ideal ... the hero is tough and strong, [and] that the West made him that way" (Tompkins 11). The Western genre, including film, novel and art, stresses the "importance of manhood as an ideal" (Tompkins 17) and demands that its heroes be self-righteous, silent, and exhibit a "pathetic determination to be tough" (Tompkins 19). The narrative of the Western hero, the Cowboy (and it is always a boy), is emblematic of not just the West, but of the United States itself from as early as 1908 when "Indian and cowboy pictures" became the top American film export to Europe (Simmon 9). Despite evidence that the cowboy character of early novels and films fought for clearly progressive idealsindividualism, gun control, environmental protection, and the benefits of community-the Western's iconic hero is most closely associated with modern day conservativism-free market, small government, rugged individualism, Puritan work ethic-particularly after the 1980 election of the cowboy actor, Ronald Reagan, who, before entering politics, starred in numerous Western films. The nostalgic belief in "cowboy values" persists today despite, as Douglas Brode argues, having no basis in the life and experience of actual cowboys. ${ }^{1}$ The Western or Frontier myth is a pop culture creation, an "elaborate fantasy of who we were" and is (still) held as the ideal for who we "ought to again become" (Brode 12). The Cowboy, always a part of the American mythos, born from dime novels, radio, film and TV, has enjoyed a resurgence with the election of Donald Trump to the US presidency in 2016. Though not a cowboy at all in the traditional sense, Trump's public performance of rugged individualism and the flouting of what conservatives see as "elite" cultural norms (intellectualism, science, multiculturalism), have lent support to his campaign slogan of "Make America Great Again,” a bold call to grass-roots conservatives and nationalists that promised a return to that golden age when white men reigned supreme and women and people of color "knew their place."

And so it makes sense, historically, for Martin McDonagh to locate his award winning film Three Billboards Outside Ebbing, Missouri in Missourigateway to the West and the Frontier Myth, a region emblematic of US

As Douglas Brode explains a real cowboy was a "poorly paid, blue-collar worker who rode the range during the nineteenth century" and often on a well-used horse (10). Henry Nash Smith, in Virgin Land: The American West as Symbol and Myth, explains "the term 'herder' was as likely to be used as the classic name for 'cowboy,' and it usually called up teh image of a semibarbarous laborer who lived a dull, monotonous life of hard fare and poor shelter" (109). In 1874, Laura Winthrop Johnson described the cowboys she saw in Wyoming as "rough men with shaggy hair and wild, staring eyes, in butternut trousers stuffed into great rough boots" (qtd. in Smith 109). 
expansion, racial tension past and present, and also the birthplace of a new Civil Rights Movement, Black Lives Matter.

In this paper, I will argue that the racial framework of Martin McDonagh's 2017 film Three Billboards Outside Ebbing, Missouri rests at the intersection of three persistent cultural myths - the Frontier Myth, the hero cowboy and the myth of white supremacy. There has been much criticism of the portrayal of black characters in the film, and particularly the lack of significant black characters in a film that sports a solid undercurrent of racial politics. While the black characters in the film occupy a small amount of screen time, I will argue that the film's treatment of black characters, including their absence, puts on display the cultural dysfunction of racial politics in the US, especially in rural America, and particularly in Missouri. As I will show, the film's performance of the Frontier Myth could be seen as a critique of the events in Ferguson, Missouri, when a white police officer shot and killed an unarmed black teenager, sparking a growing movement against the rise of overt racism in America. The film's subversion of the cowboy hero instead reveals the disturbing reality of the Frontier Myth and its dependence on racism and white supremacy for validation. In its unmasking of myth, Three Billboards challenges the illusion of a glorious Western past that never existed and at the same time supports racial justice and the Black Lives Matter movement.

\section{THE WEST[ERN] IN THE WEST}

In "Myth Today" Roland Barthes explains that myth functions as language "adapted to a certain type of consumption" in which objects, images, or any text are "laden ... with a type of social usage" (Barthes 54). Barthes believes that "the language of myth is not arbitrary, it is motivated, ideologically loaded, and responsible for transforming 'history into nature" (Barthes 53). No myth has been more effective in transforming "history into nature" than the American Western, or Frontier myth. The myth encompasses a specific geographic space (wide open plains or untamed mountain country) and centers around the Cowboy figure, a lone, rugged, individualist who shuns polite society and city life, who packs a rifle or 6-shooter (or both), who rides a valiant steed (a beautiful and spirited horse), who fights for justice and the "American" way (democracy and freedom) by "taming" the wilderness and the "savages," and whose humble beginnings reflect the notion of the Everyman/woman who is easy to identify with. The Frontier Myth has been replicated in a wide variety of ways: in literature, art, folklore, visual media, traditions, food, material culture and even politics. It is a myth that became the bedrock of the American cultural character. 
Jane Tompkins describes the West of the Western myth as a "place where technology was primitive, physical conditions harsh, the social infrastructure nonexistent, and the presence of women proportionally reduced" (Tompkins 45). Richard Slotkin explains the Frontier Myth as "the conquest of the wilderness and the subjugation or displacement of the Native Americans who originally inhabited it" (10). In the United States, these two elements combined to create a "national identity, a democratic polity, an ever-expanding economy, and a phenomenally dynamic and 'progressive' civilization" (10). For Slotkin, the Frontier Myth encapsulated the Western expansion within specific binary conflicts of nature vs. civilization, primitive or savage vs. civilized, "settler-state vs. European metropolis" (10).These ideas of conquest were certainly not new or unique to America; writers and journalists merely applied longheld colonial ideologies to the settlement of the American frontier. But it is perhaps Stephen McVeigh, in The American Western, who most clearly captures the mythology of the West,

which emerged at the beginning of the twentieth century [and] did not appear organically or naturally. Rather, the mythology was deliberately constructed to serve a purpose ... [its origins] bound up in the upheaval of the 1890s, a decade ... that saw America's self-concept, as a place of equality, opportunity, virtue and idealism, corrupted by unregulated big business, exploitation of markets, labor disputes, and political protests. On witnessing such rapid and traumatic change, Americans became nostalgic for a simpler version of America ... it is [in] this nostalgic longing that the urge towards mythology can be found. [Writers] took the frontier as the embodiment of all that was good about America, presenting it as a place of tradition, inspiration, and heroism, the arena in which the American character was forged in the past, and the repository of these values which could heal America's ills in the present. (McVeigh 13)

And so the Frontier Myth, born in the literary traditions of James Fenimore Cooper and his Leatherstocking Tales, Deadwood Dick, The Lone Ranger, Buffalo Bill and Louis L'Amour, has been an integral part of the American cultural landscape, particularly in American notions of heroism and who a hero is. The genre evolved from the written word to find its purest form in film under the masterful work of director John Ford and many others. As the hero of the Western myth evolved, the fetishistic admiration for the "rugged individual" converged with and shaped notions of masculinity, law and order, and race in American culture. The influence of the cowboy cultural myth affects ideas of masculinity even today, reinforce in the popular action hero films that follow a "Western" trajectory: Independence 
Day (1996), The Matrix (1999), Indiana Jones films, Rambo films, The Terminator films, and almost all of the super-hero Marvel and DC films contain the "cowboy" character.

The Hollywood Western film has of course played a significant role in the ways Americans think about "the cowboy" character. As Steve Anderson observes, "like history, cultural memories are produced and must be understood in relation to an array of cultural and ideological forces" (21) that work in tandem at different times in American history to both reaffirm cultural myths or challenge them. One way culture mythologizes the Frontier is by accepting the myth as collective memory-believing that this is what the West was "really like." When proponents of the myth are confronted with historical fact, it is labeled "revisionist" history (as opposed to just "history") for daring to challenge the myth. Foucault explains that for the dominant power group it is "vital to have possession of this memory, to control it, to administer it, to tell it what it must contain" (93). And what the Frontier Myth must contain is a hero cowboy who protects innocent [white] people from the bad Other. Foucault states that "there's a battle for and around history going on [with the] ... intention ... to reprogram, to stifle" actual history in favor of the popular mythic memory so as "to propose and impose on people a framework in which to interpret the present," not through the realities of the past, but through the myth of the past (102). We see this functioning in John Ford's famous film The Man Who Shot Liberty Valance (1962) in which Ford "deconstruct [s] the very myths he had earlier helped create" (Brode 13), summed up in Maxwell Scott's line: "This is the West, sir. When the legend becomes fact, print the legend."

Within the Frontier Myth is the "longing for a time when large men walked the earth" (Corkin 226), positioning the cowboy character "not [as] part of the actual, but part of the [im]possible" past, and so to be nostalgically "set at a distance" in which the myth itself becomes politically and culturally idealized and reified (Foucault 102). As a result, the Frontier Myth has become a powerful cultural memory that undergirds the core narrative of the American hero, particularly in film.

\section{THE LAWMAN}

For Jane Tompkins, “ $[\mathrm{t}]$ he Western doesn't have anything to do with the West as such. It isn't about the encounter between civilization and the frontier. It is about men's fear of losing their mastery, and hence their identity, both of which the Western tirelessly reinvents" (45). While there have been some notable Western narratives whose protagonists are 
women-The Furies (Mann, 1950) starring Barbara Stanwyck, Annie Get Your Gun (Sidney, 1950) with Judy Garland, Calamity Jane (Butler, 1953) with Doris Day, Belle Starr (Alonzo, 1980) starring Elizabeth Montgomery, and The Quick and the Dead (Raimi, 1995) starring Sharon Stone to name a few-the majority of Western narratives feature a white male protagonist. The Frontier Myth is a myth about men, manliness and manly conquest, of both nature and the Other, traditionally Native Americans. It is a narrative that takes place "between men, outside the world of women," but takes place in wide open, virgin spaces that are framed as ready for conquest and domination by the white male (Simmon 24). For Tompkins, "the Western is secular, materialist, and antifeminist; it focuses on conflict in public space, is obsessed by death, and worships the phallus ... it is a narrative of [white] male violence" (28). As Stanley Corkin explains, the Western

looks back to an idealized conception of the "frontier" experience, that is, the defining moments of U.S. imperialism when the "traditions" of indigenous peoples or of those outside the social and economic systems of the United States were disregarded, when inhabited lands with their own histories were treated as though they were virgin lands. (234)

The nostalgic longing for mastery over the wild frontier transformed during the modern age. At one point the Cold War space race between the United States and Russia revived the Frontier Myth, only here the Frontier was space. The Western narrative permeated Cold War era films and television as the competition between communism and democracy for the conquest of the "new frontiers" of ideology, production and consumption framed many Cold War narratives. And while the Frontier Myth and its hero cowboy have always been a mainstay of Hollywood film narrative, today the idealized Frontier Myth has reemerged in a far different form: in the return of nationalism, and the nostalgic lament to "Make America Great Again," a reactionary code for white supremacy and male dominance that grew from white fear of a growing multicultural population, ongoing economic uncertainty and immobility, and post-modern challenges to traditional ideologies.

The Frontier Myth relies on the civilization vs. savage opposition, epitomized in films that feature the "Lawman," a cowboy-turned-sheriff who tries to bring "civilization" to the "wilderness." Films such as Stagecoach (Ford 1939), High Noon (Zinneman 1952), How the West Was Won (Ford, 1962), True Grit (Hathaway, 1969), Hang'em High (Post, 1968), Unforgiven (Eastwood, 1992) and Tombstone (Cosmatos, 1993) feature lawmen who try to protect the burgeoning American democracy from the corruption of cityslickers, capitalists, or savages, usually Native Americans. This battle between civilized and savage was framed as a battle between good (America) 
and evil (anyone of color). As Mark Cronlund Anderson astutely argues, the Frontier Myth relies on conflict, and the Western film "revels in violence" (314). M. Anderson offers an outline of the common Frontier narrative: if there is a problem, " $[\mathrm{t}]$ he Other started it; the Other is to blame; the Other must and will be punished til the hegemon [the US, the white male] is satisfied that the Other has come to fear and adore it" (315). The "hegemon," based on Antonio Gramsci's notion of the hegemony, the ruling class who manipulate and control the culture of those below them, is found in modern lawmen - police officers-as well. According to a study by Anastasia Prokos and Irene Padavic, "hegemonic masculinity is a central defining concept in the culture of police work in the United States" (442). Michael Bohnke asserts that the Frontier Myth and the Western film often frame law in the context of conflict: the "law as written word (coming usually from the East) and those values and rules established in the community" (48). Modern police officers then, whose very training positions them as literal cowboys, ${ }^{2}$ function in ways that ideologically "quarantine the misdirected and potential threats to civil society" (Corkin 151) in order to preserve the idea of the American West.

Police today have been under close scrutiny following a long series of police brutality incidents caught on video, including the killing of innocent adults and children of color. ${ }^{3}$ These video captures of lawmen behaving badly essentially function as embodiments of the Frontier Myth's "savage vs. civilization" conflict. This is not to say that people of color are savage, but that the police, the lawman (or woman), through already established racial conflict between whites and African Americans, position people of color as savage-both at the moment of confrontation and in its digital replication on social media and other platforms. There is a long history in the US of law enforcement complicity in upholding Jim Crow and other racist social norms. As Prokos and Padavic's study shows, American police officers "share a myth of policing as action-filled, exciting, adventurous, and dangerous ... Regardless of the reality, male police officers cling to the image of police officers as crime fighters" and cowboys (442). These

2 Beverly J. Stoeltje, in "Cowboys and Clowns: Rodeo Specialists and the Ideology of Work and Play," examines the transformation of the cowboy from guy working cattle on the range to "second generation" cowboys that included "manager, lawman, cattleman," to the modern cowboy who is college educated, tech savvy, and concerned with participating in rodeos rather than riding the range (147-48).

3 See "Black Lives Upended by Policing: The Raw Videos Sparking Outrage," The New York Times, 19 Apr. 2018. https://www.nytimes.com/interactive/2017/08/19/us/ police-videos-race.html; Kia Gregory "Killing Us Softly: How Videos of Police Brutality Traumatize African Americans and Undermine the Search for Justice.” The New Republic 13 Feb. 2018. https://newrepublic.com/article/153103/videos-police-brutality-traumatizeafrican-americans-undermine-search-justice 
myths about action-packed policing are influenced to a certain extent by the Hollywood film hero, whose narrative, from early Ford Westerns to Quentin Tarantino's The Hateful Eight (2015), plays out over and over again on screen as a uniquely "American mythology, and the heroic style based on that mythology, thus provides American officers with the wrong set of symbols for measuring 'tough-mindedness"” (Slotkin 529). And so the image of the "cowboy cop" in film reinforces the belief in a heroic white masculinity that is in constant battle with the Other to preserve the myth of the Great White West. And nowhere does the Frontier Myth's performance resonate more than in the border state of Missouri.

\section{RACE IN MISSOURI}

The Frontier Myth finds clear expression in the state of Missouri, where the battles between "farmers and city-dwellers," white and black, frame both class and racial conflicts (Slotkin 20). As a border state, Missouri has held a unique position within US racial politics. Ironically, the state seal of Missouri includes the phrase "united we stand, divided we fall," an apt description of the state's long history as a land of divided interests: north/ south, urban/agrarian, slave/free, conservative/progressive. Joe Conason observes that, "for decades, Missouri has spawned or attracted many of the nation's most virulent racists, including neo-Nazis and the remnants of the once-powerful Ku Klux Klan." St. Louis, Missouri, is home base for the white supremacist group The Council of Conservative Citizens, a group that has publicly backed white nationalist candidates, including former Mississippi senator Trent Lott. As Joseph P. Williams explains, " $[\mathrm{t}]$ he Show-Me State is, geographically and culturally, almost equidistant between North and South, its status as a 'purple' political battleground [is] defined in part by its urban population and agrarian roots." In Race and Meaning: The African American Experience in Missouri, Gary R. Kremer states that Missouri is neither "completely Northern or Southern," and so did not participate in the "rigid, legal, segregation that characterized the post-Civil War South," but that they were not "any less racist" (16). For Kremer, Missouri's racism is "more often subtle and disguised" (16) but still very much a part of the landscape.

In August of 2017 the NAACP issued a travel advisory for African Americans against any travel to Missouri, the first time it has ever issued such an advisory against a state (Cummings). In response, Danielle C. Belton, editor-in-chief of The Root, published an impassioned plea for her family to leave the state, describing the "widespread systemic racism" she experienced growing up and where 
years after the Ferguson protests, activists and leaders from the movement keep popping up dead. A place where racial apathy is real. A place where they just reduced the minimum wage and where a meth epidemic has been roiling the rural areas for at least a decade or more.

Missouri was also the home of Dred Scott (Dred Scott v. Sandford), a slave who sued for American citizenship and lost, adding fuel to the economic panic of 1857 and bolstering racism throughout the South. ${ }^{4}$ Missouri was the center of the fight over whether to admit new territory as slave states, a fight that led to the Civil War. The state was also the home of Elijah Lovejoy, editor of the widely-read abolitionist newspaper, The Observer, published in St. Louis until 1867 when Lovejoy was attacked and killed by a pro-slavery mob as they tried to burn down the building that housed his printing press. His death spurred more interest in the abolition movement ("Elijah Lovejoy"). Missouri's unique political and racial climate has made it "one of the country's most fertile breeding grounds for racial strife" (Williams) or, as Daniel Marans and Mariah Stewart describe it, an "unfortunate sweet spot for racial resentment."

It is fitting, then, that St. Louis, Missouri, known for its Gateway Arch, a monument to the Western expansion and the Frontier Myth, built in 1965 in the middle of the Civil Rights Movement, became the birthplace of a new civil rights movement, Black Lives Matter, following the killing of unarmed, 18-year-old Michael Brown by a 28-year-old, white Ferguson police officer, Darren Wilson. Wilson shot Brown in Ferguson, Missouri, a northern suburb of St. Louis on 9 August 2014. That shooting sparked local protests that soon spread to an international movement against police killings of people of color, and against the disturbing instances of overt racism seen in American society and disseminated regularly on social media. The Brown shooting inspired three waves of protests and riots in Ferguson that lasted until August 2015 and set in motion an international resistance movement against racism. ${ }^{5}$ The rise in police shootings of unarmed, and often innocent African Americans (both male and female,

4 See the case ("The Case of Dred Scott in the United States Supreme Court") at: https://www.loc.gov/item/10034357/ and the Panic of 1857. After the Supreme Court decided against Dred Scott, some industries-particularly the railroad-lost ground as people were concerned about the expansion of slavery into new territories. See Charles W. Calomiris and Larry Schweikart "The Panic of 1857: Origins, Transmission, and Containment." Journal of Economic History 51.4 (1991): 807-34.

5 See "Ferguson Unrest: From Shooting to Nationwide Protests." https://www.bbc. com/news/world-us-canada-30193354; or Annys Shin "Recalling the Protests, Riots After the Police Shooting of Michael Brown.” Washington Post 3 Aug. 2017. https://www.washingtonpost. $\mathrm{com} /$ lifestyle/magazine/recalling-the-protests-riots-after-fatal-police-shooting-of-michaelbrown/2017/08/01/9992f044-5a8d-11e7-a9f6-7c3296387341_story.html 
child and adult) has emerged, intentionally or not, as a rearticulation and reaffirmation of the white supremacy narrative rooted firmly in the Frontier Myth, which Richard Slotkin defines as "the conquest of the wilderness and the subjugation or displacement of the Native Americans who originally inhabited it" and has been "the means to our achievement of a national identity" (Slotkin 10). Within the myth, any person of color fulfills the position of the Other that must be subjugated colonial-style. And so it is also fitting that Martin McDonagh set his screenplay about small-town America race relations in Missouri.

Irish filmmaker Martin McDonagh wrote the screenplay and directed Three Billboards with Graham Broadbent and Peter Czernin of Blueprint Pictures producing it for $\$ 15$ million. To date, the film has garnered $\$ 159 \mathrm{~m}$ worldwide ("Three Billboards"). McDonagh was inspired to write the screenplay because he saw similar billboards 20 years ago while he was travelling across the American South on a bus. He was struck by the "the pain and rage and sadness of the person who would put that out there." The image stayed with McDonagh and in 2011 he wrote the script, returning to it in 2015, one year after Ferguson (Abramovitch). McDonagh's story takes place in the fictional town of Ebbing, situated in the Missouri Ozarks, but he and his production crew chose to film it in Sylva, North Carolina, through May and June of 2016. But for all of McDonagh's inspiration, he is still an outsider looking in at the complexities of race and small town politics in America. For McDonagh, the experience of scouting locations throughout the Midwest and South seemed to reinforce his pastoral image of America: "every little town I go to feels cinematic" (Mueller). McDonagh states that he "just listen[ed] to people and observe[ed] - the more you do that, the less judgmental you become about red states and blue states and all that kind of stuff" (Mueller), a sentiment that simplifies complex economic, political, social and racial issues that the South has struggled with since its founding. This reduction of complex racial issues is part of the criticisms of Three Billboards; yet, as astute as some critics are that McDonagh elides the

6 See Matt Mueller "Martin McDonagh on the Real-Life Inspiration Behind Three Billboards Outside Ebbing, Missouri." Screen Daily 8 Jan. 2018. https://www.screendaily. $\mathrm{com} /$ features/martin-mcdonagh-on-the-inspiration-behind-three-billboards/5125213. article

The signs McDonagh saw were in Vidor, Texas, about the murder of 34-year-old Kathy Page, whose strangled body was found in her car in a ditch in 1991. Her father, James Fulton, frustrated by the lack of movement on the case, placed various billboards along Highway 10 in the hopes of solving the case. It remains unsolved. See Criss: https://www. cnn.com/2018/04/18/us/texas-three-billboards-reward-trnd/index.html; "Kathy Page": http://unsolvedmysteries.wikia.com/wiki/Kathy_Page 
realities of racial politics in the small-town American South, I believe the film's treatment of race is a clear denunciation of American racism.

McDonagh insists the film is "not a European's comment on America at all" (Mueller) and yet, it is. In some sense, the characters in the film are representative of both European humanism and the stereotypical American South: half of the characters are compassionate, educated, driven by rationality and humanistic responses while the other half is uneducated, lacks compassion, is hard-nosed, crass, and racist or prejudiced against difference. McDonagh's film highlights that special brand of American Southern racism that produced slavery, Jim Crow and Ferguson in such a way that it is unmasked, challenged and ultimately revealed as a cultural dead end.

\section{BLACK AND BLUE}

As I have argued elsewhere, part of the work of institutional racism in America is to present blackness as strange or different, as not normal, in order to validate whiteness as the norm (Olson). In Framing Blackness, Ed Guerrero argues that Hollywood representations of black people position them as "subordinated, marginalized, positioned, and devalued in every possible manner to glorify and relentlessly hold in place the whitedominated symbolic order and racial hierarchy of American Society" (2). In White Screens, Black Images, James Snead suggests that "the nature of stereotypes is to insulate themselves [whites] from historical change, or from counter-examples in the real world. Caricatures breed more Caricatures, or metamorphose into more harmless forms, or simply repeat," which we see throughout the history of Hollywood cinema's portrayal of black people (140). As Frantz Fanon famously wrote, blacks are always positioned to "experience [their] being through others" (82). Nowhere is this phenomenon more utilized than in Hollywood films where the black experience is regularly filtered through whiteness. In Hollywood film, black characters are often made narratively invisible or mute in the sense that their presence has little or no bearing on events, or whites speak for them and tell their story (as in Blood Diamond, Men of Honor, or The Help). Hollywood's black characters often lack depth or complexity when compared to the white characters, or the black characters are "helped" by the white storyteller.7 In Three Billboards

7 Dubbed the "white savior" trope in cinema. See Matthew Hughy The White Savior Film: Content, Critics, and Consumption (2014); Hernán Vera and Andrew M. Gordon Screen Saviors: Hollywood Fictions of Whiteness (2003). 
we learn about the black experience in Missouri through Dixon and the disturbingly casual references to his torture of a black person in his custody. His name "Jason Dixon" is a clear reference to the "MasonDixon" line, the historical line between Southern slave and Northern free states, dividing Pennsylvania from Maryland. The name "Dixon" is also a reference to Thomas Dixon, author of The Clansman (1905), the novel that was the basis for D. W. Griffith's racist film Birth of a Nation (1916), the first American full-length, 12-reel, film. And Dixon is very much representative of the Old South ideology: an elevated sense of white privilege, conservative, stubbornly defending racist traditions. Dixon is uneducated (his mother jokes about his 5 years at the academy, "6, counting the year you were held back"), volatile, childish, and immature. Any shot of Dixon at the police station has him looking at comics, dancing, singing, or feet on the desk, showing a clear lack of respect for the job and his role as a law enforcement officer.

We are cautioned early on about Dixon when Mildred makes snide remarks about Ebbing police being "too busy torturing black folks to solve real crime." Our first view of Dixon's interaction with a black person is when Dixon confronts Jerome about the billboards. The shot is balanced by Dixon's car lower screen left, the red billboard upper screen right, and Jerome centered between them suggesting blackness in Missouri is caught between the threat of law enforcement and the lack of oversight of law enforcement. The sign's message "Still No Arrests?" holds a double entendre-no arrests in Angela's murder and Dixon was not arrested for his torture of a black man. When Dixon later attacks Red he is also not arrested, though he is fired, mirroring the earlier question "Still No Arrests?”

Despite Dixon's performance of machismo, Jerome is not afraid of Dixon. When Dixon obnoxiously demands "What the fuck is this?", Jerome doesn't miss a beat and quickly repeats back the profanity: "What the fuck is what?" Jerome easily thwarts Dixon's attempt at controlling the confrontation and when Dixon asks "What is it advertising?", Jerome answers: "Something obscure?", leaving Dixon flustered, mumbling a weak "Yeah, I'll say." The film here, as it does with the other black characters, positions Jerome as intellectually and morally superior to Dixon. Jerome then asks, "Don't I know your face from someplace?" and Dixon replies, "I don't know, do ya?", to which Jerome slowly and deliberately replies "Yes-yes I do", then promptly spits on the ground towards Dixon, who then threatens to arrest him for illegally dumping his bucket, which is against the "being bad against the environment" laws. Jerome here is unafraid, firm but polite, and clearly knows the danger he is in in any exchange with Dixon. Yet, Jerome has the upper hand here and tells Dixon 
to go look at the first billboard and then come back and they can "have a conversation about the motherfucking environment. How "bout that." Since Dixon is in his car during this exchange the camera positions him lower than Jerome, reinforcing Dixon's weakness and Jerome's command of the exchange. Dixon is in very low light, irresolute, almost hiding in his cave-like car while Jerome is lit slightly more and Dixon must look up at him, speaks clearly and unabashedly, highlighting his contempt for Dixon. Jerome is supported by the deep scarlet of the billboard behind him, adding texture to his contempt for Dixon. And while the billboards perform a dual spectacularization of Mildred's deep-seated (red) rage at her daughter's murder and the lack of law enforcement attention, the deep red of the billboards also underscores black rage at the "persons of color" torture by law enforcement.

Spitting is a particular trope in Three Billboards, as it is in throughout the Western film genre (some of the most memorable spits come from Clint Eastwood in The Good, The Bad, and The Ugly, The Outlaw Josey Wales and High Plains Drifter). ${ }^{8}$ According to Esther Addley, "spitting retains an offensiveness beyond ... all, rivaling perhaps only the racist insult in its capacity to outrage," not to mention the "glorious contemptuousness" and "effortless momentary disrespect it conveys." When Jerome spits towards Dixon, his verbal contempt gains materiality in the projectile of saliva and his "phallic genital superiority [is] asserted" (Gomberg 93). Later in the film, Mildred spits on the Dentist after she drills through his hand, Willoughby coughs/spits blood in Mildred's face (she immediately shifts to "mom" mode, asking if he's ok and calls him "baby"), and just before Dixon throws Red out the window he spits on him. Spitting in Three Billboards is a discursive expression of powerlessness, as well as disgust or contempt. Jerome cannot physically attack Dixon, so he spits at him instead. Willoughby's cancer makes him powerless, and Mildred is powerless in two ways: she is riddled with guilt about, and she cannot solve, her daughter's murder. In Dixon's case, spitting on Red (because he could not spit on Jerome) only foregrounds Dixon's powerlessness, his lack of emotional and moral control. In fact, for Dixon, Red serves as the substitute for the (red) billboards that Dixon feels destroyed Willoughby. Dixon tortures Red like he tortured the black person in his custody. As Dixon delivers one last punch to Red, he says: "See, Red, I got issues with white folks too," which rings false as we understand Red to be the substitute for the billboards themselves, or for Mildred, and not as a representative of a race.

For a collection of some of the most famous Western film spits see Semih Okmen "Western Spittle": https://vimeo.com/174031604 


\section{LAWMEN AND THEIR MOTHERS}

The law itself in the film is an unsettling matrix of fear of the other, white entitlement and the institutional sanction of violence against people of color. In the police station when Dixon and Cedric argue over whether or not the billboards are legal, Dixon storms out and Cedric asks Willoughby why he "keeps [Dixon] on?" Willoughby replies: "He's a good man at heart." Here Cedric exposes Dixon's unsuitability for the job by reminding Willoughby that Dixon tortured a guy in custody. Willoughby offers a hesitant and unconvincing reply, "There was no-real evidence of that," underscoring a law enforcement culture that enables such racism-and denial of racismwithin its ranks. According to Michael Harriot, "since June 2007, out of approximately 10,000 police shootings, only five white police officers have been imprisoned for killing someone black." This intersection of white entitlement and race speaks to the broader issue of the way traditionalists fetishize nostalgia, or as Brode states, the way "conservative-minded Americans believe they can be [powerful] again" and revive the West as such: the belief in an "American greatness" and a "return" to "law and order" (i.e. the conservative rally cry to "Make America Great Again") in which the white male was the unquestioned authority (327). Dixon is McDonagh's caricature of that white male angst in the face of a changing culture. Popular narratives of White Western greatness are a part of the cultural tensions our nation experiences today as its identity continues to evolve away from the Cowboy and Frontier Myth (i.e. whiteness) and towards multiculturalism, progressiveness, secularity and social consciousness. Ideas about old-style manhood and law and order in such popular novels as Legends of the Fall by Jim Harrison, Blood Meridian by Cormac McCarthy or The Revenant by Michael Punke work to keep the "collective social imaginary" (Appadurai 220) nostalgia for the Old West and what it represents alive as do popular Western films like Unforgiven (1992), The Assassination of Jesse James by the Coward Robert Ford (2007) and Meek's Cutoff (2010). Even Dixon's comic book choice suggests his enthrallment with the hero Cowboy myth: Incorruptible (Boom! Studios), a comic series by Mark Waid about a villain named Max Damage who wants to be a superhero (the parallels to Dixon are quite clear).

Oddly, Dixon occupies the paradoxical position of being both a police officer, the representation of law and order, and villain-he terrorizes black people and is filled with villainous attributes like cruelty, violence, small-mindedness and racism. McDonagh's Dixon suggests such conflicts within law enforcement are the norm in the rural US, which he then challenges at films end with the arrival of Abercrombe, the embodiment of the social change that Dixon himself acknowledged when his mother 
suggested he go and "tell them to fire that black guy": "Things have moved on in the South" to which is mother replies: "Well it shouldna!" Today's convergence of rising nationalism, militarization of local police forces and increasing racism fueled, in part, by a steady barrage of "fear of the other" narratives by conservative pundits and politicians have played a part in the deadly violence against African Americans by law enforcement, such as in Ferguson and in the fictional Ebbing. As Matthew Carter explains, Dixon "highlight $[\mathrm{s}]$ the symptomatic hubristic condition of US selfrighteousness" and particularly in this age of Trump (6). Although Dixon grudgingly accepts that the man from Idaho didn't kill Mildred's daughter, he convinces himself the man is guilty of "something," a mental justification that allows Dixon to achieve a (false) moral position, a self-righteousness. Jane Tompkins explains that "the Western plot ... turns not on struggles to conquer sin but on external conflicts in which men prove their courage to themselves and the world by facing their own annihilation" (Tompkins 31). At the film's end, Dixon, now in an Oedipal partnership with Mildred, who has merely replaced his mother as his guide, head to Idaho to kill an innocent man. Dixon insists on proving to himself (and to Willoughby) that he can "detect," and that he can be a "good cop."

\section{MARGINAL IN MISSOURI}

Black characters in Three Billboards are rational, humanistic, well-educated and have a high moral center (in contrast to Dixon, Willoughby and Mildred). At the moment when Dixon crosses into the police station after attacking Red, we hear the extra-diegetic song lyrics "he hears his Master's voice, he hears the call to war" as we see Abercrombie for the first time. (Carter Burwell scored Three Billboards and was influenced by the Spaghetti Westerns of the 1970s, particularly those by Sergio Leone [Maniglia].) As Dixon walks to the station, he says to Abercrombie, "What the fuck you lookin' at?" which suggests both change-his new "master" now will be African American—and Dixon as an object of a contemptuous gaze as Abercrombie's arrival signals an end to the old South that Dixon represents.

While race remains a constant subtext throughout the film, we never actually see Dixon physically hurting anyone of color. In fact, when confronted by African Americans in the film (Jerome and Abercrombie), Dixon backs down. In Three Billboards, McDonagh effectively reverses our perspective of Otherness and renders Mildred, her ex, Charlie, his 19-year-old girlfriend Penelope, Dixon, Cedric and the other racist cops as the strange and different, as remnants of an old West that "no longer 
holds true" (Brode 326). The black characters-Jerome, Denise and Abercrombie-and James, Red and Robbie are the people who act with moral and social decency. The black and marginal characters are the only characters who come out the other side with dignity intact. As Wesley Morris observes, McDonagh

[p]lay[s] around with America's ideological and geographical toys. One of the toys is the word "nigger." Another is the concept of political correctness. There's a scene between Mildred and a hotheaded dimwit cop—the racist—named Jason (Sam Rockwell), in which she baits his racism by calling him a "nigger torturer." He hits the roof. "Person-ofcolor-torturing" is what Jason says you must call it now, with exasperated lament. They volley the word and poke fun at its impropriety. You can tell that Mr. McDonagh relished the application of absurdism to the political correction (he knows "person-of-color-torturing" really is linguistic torture, maybe even for a person of color). But he also seems to like the loaded nonsense in the sound of the word "nigger." What you hear in a scene like this is a kind of careless virtuosity. It's a fun scene that's sunk by how much fun it's having with things you're not supposed to have fun with. The whole movie is like that-it's like Mildred-rude for sport and proud of it.

And Morris is right to a certain extent; the film does exploit the sheer absurdity of racism and Othering. The little person, James, is a victim of Mildred's discrimination. She continually demeans him even after he covered for her when she torched the police station. She reluctantly agrees to have dinner with him, but treats him unkindly and insultingly justifies to Charlie why she is having dinner with a "midget." But James berates Mildred and her behavior towards him, effectively shaming her and walking away with his dignity intact, much like the black characters do after interactions with whites in the film. Even Denise, who Dixon arrests for possessing marijuana, has the last laugh as she joins Jerome, Mildred and others to rehang the billboards after Dixon burns them. In effect, Dixon is the embodiment of what James J. Donahue terms the "failed frontiersman," who clings to the Frontier Myth even in the face of its ideological barrenness (1). bell hooks in "Eating the Other" states that Otherness "offers the promise of recognition and reconciliation," at the same time that it fosters "nostalgic evocation of a 'glorious' past," a past that Dixon longs for, but cannot return to (370).

One of the ways McDonagh's film comments on race is through the concept of "seeing by not seeing," or, in Derrida's terms, absence as presence. Derrida's notion of "there is nothing outside of the text" clearly "demonstrates that it is impossible for signification to be absolutely 
present" (158). In doing so, he proves that only through mediated forms like language can one access signification. Importantly, for media theory, representational absence becomes a form of presence" (Bell). The film's rhetoric continually dances around racism, yet the visual absence of the racial violence the rhetoric tells us exists functions only to bighlight that violence-its absence becomes its presence. By "not seeing" Dixon torture or hurt black characters, but "hearing" about it, McDonagh forces the non-visual (i.e. the elephant) into the room. It is similar to action that we "hear" taking place in off-screen space; we know that action occurred, its echo stays with us." By "not seeing" actual racial violence in Three Billboards, McDonagh effectively renders such violence "loud" in its absence, bringing it to the forefront and reifying its existence, particularly as the black characters in the film all appear better educated and more compassionate than the white characters (Mildred's son is an exception). And we know Dixon is violent; we witness his unprovoked and needless attack on Red. We know he is racist from the first time we see him: he's driving and singing an old Western ballad, "The Streets of Laredo," also known as "The Cowboy's Lament" about a dying cowboy, foreshadowing Dixon's, and the Old South's, symbolic "death" in the face of progress and integration. As Dixon comes upon the billboards he pulls over to find out "what" they are, calling one of the men hanging the billboard a "beaner," a slang term for someone of Hispanic ancestry. We also know Dixon's racism is generational because of his mother's comments about how the South "shouldna" changed. Dixon's racism is in some ways balanced by Mildred, who is not nice to anyone except the black characters, to whom she will go out of her way to help (for instance, when she confronts Dixon about Denise's arrest). The town name itself, Ebbing, is an allusion to an "ebb" tide, an outflow of water, or, in this case, the outflow of old racist notions, to be replaced later by Abercrombie's arrival (flood tide) and Dixon's exit.

That Mildred and Dixon join forces to pursue their false sense of justice underscores the film as a cautionary tale against the abuses of the system. As Joe Sommerlad concludes about Dixon, "he isn't reformed.

9 Filmmakers often make use of off-screen space for graphic or tension-filled scenes. Some famous "off screen" scenes include in Roman Polański's Rosemary's Baby in the telephone scene. The old woman is sitting on the edge of the bed talking on the phone, but the camera angle cuts off her face. Only her back is visible-we can hear her talk, but we cannot see her face. And in Brian de Palma's Scarface, when Tony Montana is forced to watch the drug dealer cut up his friend with a chainsaw. We see and hear the chainsaw, and see blood flying, but we do not "see" the actual act itself. See Cristiano Dalpozzo "Off-Screen: The Liminal Dimension of the Cinematic Image." Refractory: A Journal of Entertainment Media. http://refractory.unimelb.edu.au/2014/02/05/off-screen-dalpozzo/ 
Far from it. The film's conclusion sees Dixon and Mildred setting out across state lines to carry out a vigilante hit on a suspected rapist in selfish pursuit of personal catharsis (they may or may not actually go through with it)," in which "retaliatory violence becomes not simply justifiable but imperative" (Tompkins 228). "His indifference to the values he once so hypocritically claimed to embody as an officer of the law remains alive and well" (Sommerlad). And Mildred's selfishness also remains: she learns nothing about being a better parent, effectively abandoning her remaining child in her pursuit to assuage her own guilt over Angela's murder. And it is this lack of growth within Dixon and Mildred that nullifies both Dixon's heroic attempt to solve Angela's murder and Mildred's billboards. Neither action brought truth or redemption. As Slavoj Žižek explains, "we overlook the way our act is already part of the state of things we are looking at, the way our error is part of the truth itself. This [is a] paradoxical structure in which the truth arises from misrecognition" (191). Rather than see the truth of the limits of law enforcement to solve the crime or to make Dixon a hero, both characters interpret those limits as apathy (Mildred) or personal criticism (Dixon). In the end, they resolve to take their "Code of the West" justice to the actual West (Idaho); a new place; but sadly, a place with a reputation for similar outdated notions (Idaho is considered the most racist state outside the South). ${ }^{10}$ Indeed, that they leave (head out, i.e. $e b b]$ Ebbing for Idaho to pursue a false justice against a presumably innocent man highlights the continued social disconnection between the old establishments of law and order [white rule] and the realities of American diversity. And with Abercrombie's arrival as the new "Law," McDonagh allies the film with social progress: Black lives do matter in Ebbing, Missouri.

\section{IN THE END}

For all the critics' applause over Dixon's seeming change of heart, the film essentially denies Dixon's redemption. That he teams up with Mildred, who is as bitter and hateful as Dixon, to hunt down and kill a man they only "suspect" of a crime, shows that neither one of them has really learned anything at all. Instead, they leave Missouri and its racist history

10 See Todd Shallat "Racial Discrimination in Idaho: The Myth of the Colorblind State." The Blue Review 4 (2014). https://thebluereview.org/racism-in-idaho/; Tim Froh "Anonymous Letters and Threats: How Racism Came to Stalk US Youth Soccer." The Guardian 15 Feb. 2018. https://www.theguardian.com/sport/2018/feb/15/us-youthsoccer-racism; the Southern Poverty Law Center interactive Hate Group map: https:// www.splcenter.org/hate-map 
to go to another place that has a very similar racist culture. Both characters abandon the only person who loves them (Dixon stares at his sleeping mother before he leaves, while the film cuts to a parallel scene with Mildred staring at her sleeping son Robbie before she leaves). As Sonny Bunch, rightly, states, the film has a

stronger message about the dangerously fascist impulse that goes along with the desire for total and perfect justice. It is a damning critique of not only the police for protecting their own but also of those who would join forces with the most corrupt among the cops in order to gain some measure of righteousness in this world. If one were feeling puckish, one might even compare Mildred's self-righteous, half-cocked pursuit of evidence-free justice against all men everywhere to certain currents in our cultural moment.

Indeed, the current reductive climate of white supremacy and race hate under the Trump administration is a testament to the conservative sociopolitical discourse which seeks the dismantling of post-modernity itself by rejecting cultural and social progress, and even science, in the name of national "greatness" and (a false) "patriotism." According to Stanley Corkin, "Westerns appeal to audiences through their power to assert a kind of stability and continuity. Typically, films in this genre invoke a tradition of national character and destiny that connects the present, a sense of the past, and a vision of the future," which we see today with the Trump phenomenon and its "Make America Great Again" slogan (59).

As Richard Sparks observes, the Western film "poeticiz[es] the struggles of its male hero" (353). And the beautiful cinematography and the Western-themed score of Three Billboards attempts to poeticize Dixon as the hero, but instead, he functions as a tear in the very fabric, or myth, of the Western as such. The film hints at this rupture when we first see Dixon as the Western trope of the "singing cowboy" because he peppers the song "Streets of Laredo" with loud "MOWs!", a verbal rupture of the most iconic of all cowboy images. And so the dysfunction in Ebbing, Missouri, the film tells us, lies with the old notions of white supremacy and racism that are bound to the Frontier Myth and, in this case, representatives of law and order. As a Lawman, Dixon is supposed to be a "protector of traditional American values against the forces that threaten to destroy" them (Brown 85). But the film makes clear that it is those traditional American myths that are the forces to be overcome. The film, like the Western genre as a whole, presents a "superficial veneer of historicity masking an essentially stylized representation whose principle debt of fidelity is to generic verisimilitude . . . rather than to the authenticated historical record" (Langford 27). With Abercrombie's 
arrival, and Dixon and Mildred's departure, the film suggests that there is hope that Ebbing will shed its racist shell and join the rest of postmodern, mostly enlightened, American society.

Most disturbingly, however, is that the nostalgic discourse of the Western and the image of the lone white male facing the "dark savage," plays out in police shootings of black and brown citizens almost every day in America, violence that often appears sanctioned by the legal system itself in the lack of consequences for the majority of the officers involved. It is the "failure of civic process and authority [that] brings further gravity ... to the heroic presence" of the law enforcement officer in the conservative Trump-era public imaginary (Corkin 148). In American society, as in Three Billboards, law enforcement holds the power in the community, and though Chief Willoughby was framed as a "good" man, he still enabled Dixon and turned a blind eye to his deputies' blatant racism and violence against innocent civilians, evidenced by his weak excuse: "What are ya gonna do?" Willoughby tells us that "there was no-real-evidence to support" the charge that Dixon tortured a black man in his custody, and Dixon is not in jail, so we can assume there were no consequences for this act. When Dixon throws Red out the window, he is not arrested or charged, even though others clearly witnessed the unprovoked assault. Dixon does lose his job, however, as many actual law enforcement officers do after a police fatality, but did Abercrombie fire Dixon because of his attack on Red or because of his insubordination? Even under Abercrombie, Dixon is still never arrested for hurting Red, but he does lose his job and with it his imagined hero role. The Frontier Myth "demands violence, supplies it, rewards it, and then projects it onto the Other" (M. Anderson 320) and in Ebbing, Missouri, violence against civilians by police is just a part of life in the West[ern], i.e. "what are ya gonna do?"

Kimberly Jade Norwood, in "The Far-reaching Shadow Cast by Ferguson," argues that the death of Michael Brown in Ferguson, Missouri, certainly not the first African American youth to be killed by police, became the catalyst for a new civil rights movement against the killing of unarmed black people. She argues that Ferguson is not special but is "representative of many similar communities throughout the country, all boiling with social ills that can no longer be ignored" (17). What Brown's death in Ferguson did was "shed light on a racial divide in this country that should shock the world," and set in motion a movement based on the twitter hashtag \#blacklivesmatter and fueled by the collective power of social media (Clayton 453). Activists for Black Lives Matter have focused their attention on protesting racial bias within law enforcement, though racial bias is prevalent throughout many areas of American society. A 2017 Washington Post study found that the majority of armed civilian 
fatalities by police were white, the majority of unarmed civilians killed by police were black, a startling statistic when blacks make up only $12 \%$ of the population as a whole (Carbonneau et al 746). Black Lives Matter is part of a continuing struggle, since the Civil Rights Movement of the 1960s, for "freedom, equity, and dignity by people of African descent," and a resistance to what Abigail Sewell calls the "American Apartheid reality" of life for black Americans throughout the United States (1444). That Missouri, in the center of the country, the "Gateway to the West," became the launch pad for modern racial unrest is emblematic of just how embedded racism is throughout the United States. The fictional Ebbing, Missouri, and its clear gap between post-modern inclusivity and Old Southern racism, suggests that change can happen-but only if Jim Crow, like Dixon, rides off into the sunset.

\section{Works Cited}

Abramovitch, Seth. "Making of Three Billboards: How a Haunting Greyhound Bus Trip Inspired the Dark Revenge Comedy." Hollywoodreporter.com. The Hollywood Reporter 12 Jan. 2018. Web. 22 Jul. 2020.

Addley, Esther. "Here's One in the Eye." Theguardian.com. The Guardian 5 Nov. 2003. Web. 22 Jul. 2020.

Anderson, Mark Cronlund. "The U.S. Frontier Myth, American Identity, and 9/11." The Journal of Psychobistory 38.4 (2011): 314-27. Print.

Anderson, Steve. "History TV and Popular Memory." Television Histories: Shaping Collective Memory in the Media Age. Ed. Gary R. Edgerton and Peter C. Rollins. Lexington: UP of Kentucky, 2001. 19-36. Print.

Appadurai, Arjun. "Disjuncture and Difference in the Global Cultural Economy." Cultural Studies Reader. Ed. Simon During. New York: Routledge, 1993. 216-27. Print.

Barthes, Roland. "Myth Today." Global Literary Theory. Ed. Richard J. Lane. New York: Routledge, 2013. 53-64. Print.

Bell, Amanda. "Absence/presence." Lucian.uchicago.edu. The Chicago School of Media Theory. Web. 22 Jul. 2020.

Belton, Danielle C. "Dear Family, Please Move Out of Mo., Love Danielle." Theroot.com. The Root 3 Aug. 2017. Web. 22 Jul. 2020.

"Black Lives Upended by Policing: The Raw Videos Sparking Outrage." Nytimes.com. The New York Times 19 Apr. 2018. Web. 22 Jul. 2020.

Bohnke, Michael. "Myth and Law in the Films of John Ford." Journal of Law and Society 28.47 (2001): 47-63. Print. https://doi.org/10.1111/14676478.00178 
Brode, Douglas. Dream West: Politics and Religion in Cowboy Movies. Austin: U of Texas P, 2013. Print.

Brown, Jeffery A. "Bullets, Buddies, and Bad Guys." Journal of Popular Film and Television 21.2 (1993): 79-87. Print. https://doi.org/10.1080 /01956051.1993.9944235

Bunch, Sonny. "What If Three Billboards Outside Ebbing, Missouri Is a Tale about Damnation, Not Redemption?" Washingtonpost.com. The Washington Post 11 Jan. 2018. Web. 22 Jul. 2020.

Calomiris, Charles W., and Larry Schweikart. "The Panic of 1857: Origins, Transmission, and Containment." Journal of Economic History 51.4 (1991): 807-34. Print.

Carbonneau, Amanda, et al. "Understanding Racial Disparities in Police Use of Force: Lessons from Fatal Police-on-Police Shootings." Journal of Social Issues 73.4 (2017): 744-67. Print. https://doi.org/10.1111/ josi.12246

Carter, Matthew. Myth of the Western. Edinburgh: Edinburgh UP, 2014. Print.

Clayton, Dewey M. "Black Lives Matter and the Civil Rights Movement: A Comparative Analysis of Two Social Movements in the United States.” Journal of Black Studies 49.5 (2018): 448-80. Print. https:// doi.org/10.1177/0021934718764099

Conason, Joe. "Missouri's Tortured History of Racism: Why the Inferno in Ferguson is No Surprise." Salon.com. Salon 21 Aug. 2014. Web. 22 Jul. 2020.

Corkin, Stanley. Cowboys as Cold Warriors: The Western and US History. Philadelphia: Temple UP, 2004. Print.

Criss, Doug. "The Reward Has Been Doubled in the Cold Case That Inspired Three Billboards Outside Ebbing, Missouri." Edition.cnn.com. CNN 18 Apr. 2018. Web. 22 Jul. 2020.

Cummings, Ian. "NAACP Issues First-ever Travel Advisory for a Stateand its Missouri." Kansascity.com. Kansas City Star 1 Aug. 2017. Web. 22 Jul. 2020.

Dalpozzo, Cristiano. "Off-Screen: The Liminal Dimension of the Cinematic Image." Refractory: A Journal of Entertainment Media 22 (2013): n.pag. Refractory.unimelb.edu.au. Web. 22 Jul. 2020.

Derrida, Jacques. Of Grammatology. Trans. Gayatri Chakravorty Spivak. Baltimore: John Hopkins, 1997. Print.

Donahue, James J. Failed Frontiersmen: White Men and Myth in the PostSixties American Historical Romance. Charlottesville: U of Virginia P, 2015. Print.

"Elijah Lovejoy." Loc.gov. Library of Congress. Web. 22 Jul. 2020.

Fanon, Frantz. Black Skin, White Masks. New York: Grove, 1952. Print. 
"Ferguson Unrest: From Shooting to Nationwide Protests." Bbc.com. BBC 10 Aug. 2015. Web. 22 Jul. 2020.

Foucault, Michel. "Film and Popular Memory." Foucault Live: Collected Interviews 1961-1984. Ed. Silvere Lotringer. New York: Semiotext(e), 1989. Print.

Froh, Tim. "Anonymous Letters and Threats: How Racism Came to Stalk US Youth Soccer." Theguardian.com. The Guardian 15 Feb. 2018. Web. 22 Jul. 2020.

Gomberg, Herbert L. "A Note on the Phallic Significance of Spitting." The Psychoanalytic Quarterly 50.1 (1981): 90-95. Print. https://doi.org/10 $.1080 / 21674086.1981 .11926945$

Gramsci, Antonio. Selections from the Prison Notebooks. London: Lawrence and Wishart, 1971. Print.

Gregory, Kia. "Killing Us Softly: How Videos of Police Brutality Traumatize African Americans and Undermine the Search for Justice." Newrepublic.com. The New Republic 13 Feb. 2018. Web. 22 Jul. 2020. Guerrero, Ed. Framing Blackness: The African American Image in Film. Philadelphia: Temple UP, 1993. Print.

Harriot, Michael. "White Men Can't Murder: Why White Cops Are Immune to the Law." Theroot.com. The Root 22 Jun. 2017. Web. 22 Jul. 2020.

hooks, bell. "Eating the Other." Media and Cultural Studies: Key Works. Ed. Meenakshi Gigi Durham and Douglas M. Kellner. Malden, MA: Blackwell, 2001. 366-80. Print.

Hughey, Matthew. The White Savior Film: Content, Critics, and Consumption. Philadelphia, PA: Temple UP, 2014. Print.

"Interactive Hate Group Map." Splcenter.org. The Southern Poverty Law Center. Web. 22 Jul. 2020.

"Kathy Page." Unsolvedmysteries.fandom.com. Fandom. Web. 22 Jul. 2020.

Kremer, Gary R. Race and Meaning: The African American Experience in Missouri. Columbia: U of Missouri P, 2014. Print.

Langford, Barry. "Revisiting the 'Revisionist' Western." Film \& History 33.2 (2003): 26-35. Print.

Maniglia, Valentin. "Going Western-Carter Burwell On Scoring Three Billboards Outside Ebbing, Missouri." Magazine.scoreit.org. Score-it Magazine 9 Feb. 2018. Web. 22 Jul. 2020.

Marans, Daniel, and Mariah Stewart. "Why Missouri Has Become the Heart of Racial Tension in America: From Ferguson to Mizzou, the Show-Me-State is Not a Focal Point." Huffingtonpost.com. Huffington Post 16 Nov. 2015. Web. 22 Jul. 2020.

McVeigh, Stephen. The American Western. Edinburgh: Edinburgh UP, 2007. Print. 
Morris, Wesley. "Does Three Billboards Have Anything to Say About America? Well ...” Nytimes.com. The New York Times 18 Jan. 2018. Web. 22 Jul. 2020.

Mueller, Matt. "Martin McDonagh on the Real-Life Inspiration Behind Three Billboards Outside Ebbing, Missouri." Screendaily.com. Screen Daily 8 Jan. 2018. Web. 22 Jul. 2020.

Norwood, Kimberly Jade. "The Far-reaching Shadow Cast by Ferguson." Washington Law Journal 46.1 (2014): 1-22. Print.

Olson, Debbie. Black Children in Hollywood Cinema: Cast in Shadow. New York: Palgrave, 2017. Print. https://doi.org/10.1007/978-3-31948273-6

Prokos, Anastasia, and Irene Padavic. "There Oughtta Be a Law Against Bitches: Masculinity Lessons in Police Academy Training." Gender, Work, and Organization 9.4 (2002): 439-59. Print. https://doi. org/10.1111/1468-0432.00168

Sewell, Abigail. "The Intersectional, Structuralist, and Anti-geneticism Centres of Black Lives Matter.” Ethnic and Racial Studies 41.8 (2018): 1443-46. Print.

Shallat, Todd. "Racial Discrimination in Idaho: The Myth of the Colorblind State." The Blue Review 4 (2014). Thebluereview.org. Web. 22 Jul. 2020.

Shin, Annys. "Recalling the Protests, Riots After the Police Shooting of Michael Brown.” Washingtonpost.com. Washington Post 3 Aug. 2017. Web. 22 Jul. 2020.

Simmon, Scott. The Invention of the Western Film: A Cultural History of the Genre's First Half-Century. Cambridge, UK: Cambridge UP, 2003. Print.

Slotkin, Richard. Gunfighter Nation: The Myth of the Frontier in Twentieth Century America. Norman: U of Oklahoma P, 1992. Print.

Smith, Henry Nash. Virgin Land: The American West as Symbol and Myth. Cambridge: Harvard UP, 1950. Print.

Snead, James. White Screens, Black Images. Ed. Colin McCabe and Cornel West. New York: Routledge, 1994. Print.

Sommerlad, Joe. "Three Billboards is Not a Racist Film. What's Truly 'Problematic' is Twitter's Appetite for Controversy." Independent. co.uk. Independent 27 Jan. 2018. Web. 22 Jul. 2020.

Sparks, Richard. "Masculinity and Heroism in the Hollywood Blockbuster." British Journal of Criminology 36.3 (1996): 348-60. Print. https://doi. org/10.1093/oxfordjournals.bjc.a014099

Stoeltje, Beverly J. "Cowboys and Clowns: Rodeo Specialists and the Ideology of Work and Play." And Other Neighborly Names: Social Process and Cultural Image in Texas. Ed. Richard Bauman and Roger D. Abrahams. Austin: U of Texas P, 2011. 123-51. Print. 
"The Case of Dred Scott in the United States Supreme Court." Loc.gov. Library of Congress. Web. 22 Jul. 2020.

The Man Who Shot Liberty Valance. Dir. John Ford. Perf. James Stewart, John Wayne. John Ford Productions, 1962. DVD.

Three Billboards Outside Ebbing, Missouri. Dir. Martin McDonagh. Perf. Frances McDormand, Sam Rockwell. Blueprint Pictures, 2017. DVD.

"Three Billboards Outside Ebbing, Missouri." Boxofficemojo.com. Box Office Mojo. Web. 22 Jul. 2020.

Tompkins, Jane. West of Everything: The Inner Life of Westerns. New York: Oxford UP, 1992. Print.

Vera, Hernán, and Andrew M. Gordon. Screen Saviors: Hollywood Fictions of Whiteness. Lanham: Rowman \& Littlefield, 2003. Print.

"Western Spittle." Semih Okmen. Online video clip. Vimeo.com. Vimeo 9 Jul. 2016. Web. 22 Jul. 2020.

Williams, Joseph P. "Welcome to Missouri and Civil Rights 2.0: LGBT Rights, Racism, and Police Use of Deadly Force Converge in a Politically Purple State." Usnews.com. US News and World Report 5 Jan. 2016. Web. 22 Jul. 2020.

Žižek, Slavoj. "The Truth Arises from Misrecognition Part 1." Lacan and the Subject of Language. Ed. Ellie Ragland-Sullivan and Mark Bracher. New York: Routledge, 1991. 188-212. Print.

\section{Debbie Olson earned her PhD from Oklahoma State} University in English/Screen Studies. Her research interests include images of African and African American children in film and television, childhood studies, cultural studies, African film and New Hollywood Cinema. She is the author of Black Children in Hollywood Cinema (Palgrave, 2017) and editor of The Child in World Cinema (2018), The Child in Post-apocalyptic Cinema (2015) and many others. She has co-edited, with Dr. Adrian Schober (Australia) Children and Youth in American Television (2018) and Children in the Films of Steven Spielberg (2017). She has written numerous book chapters, most recently "On the Innocence of Beasts: Child Soldiers in Cary Fukunaga's Beasts of No Nation" in African Childhoods, edited by Charles Quist-Adade, De-Valera Botchway and Awo Abena Amoa Sarpong (2019). She is currently at work on her next book, Counterculture Cinema: Youth in Transition.

ORCID: 0000-0002-8281-6462

debbieo@okstate.edu olsond@moval.edu 